The International Indigenous Policy Journal

\title{
New Discourses on Energy Transition as an Opportunity for Reconciliation? Analyzing Indigenous and Non-Indigenous Communications in Media and Policy Documents
}

\author{
Carelle Mang-Benza, Jamie Baxter et Romayne Smith Fullerton
}

Volume 12, numéro 2, 2021

URI : https://id.erudit.org/iderudit/1076962ar

DOI : https://doi.org/10.18584/iipj.2021.12.2.8641

Aller au sommaire du numéro

\section{Éditeur(s)}

Scholarship@Western (Western University)

ISSN

1916-5781 (numérique)

Découvrir la revue

Citer cet article

Mang-Benza, C., Baxter, J. \& Smith Fullerton, R. (2021). New Discourses on Energy Transition as an Opportunity for Reconciliation? Analyzing Indigenous and Non-Indigenous Communications in Media and Policy Documents. The International Indigenous Policy Journal, 12(2), 1-27.

https://doi.org/10.18584/iipj.2021.12.2.8641

\section{Résumé de l'article}

This article examines energy issues articulated by Indigenous and non-Indigenous people in Canada and analyzes the energy transition as a locus of reconciliation therein. Using content and discourse analysis of policy documents, white papers, and news media articles, we draw attention to reconciliation and energy discourses before and after 2015, the year that marked the release of the Truth and Reconciliation Commission of Canada (TRC) report and the Paris Agreement on climate change. We find a three-fold expansion of those discourses, which encompass issues of inclusion and exclusion, dependency, and autonomy, as well as colonial representations of Indigenous people, after 2015. We also find that non-Indigenous voices are more prominent in those conversations. We suggest that the prospects of mutual benefits could turn the energy transition into an opportunity to bring together Indigenous and non-Indigenous people in Canada. 
Volume 12 | Issue 2

April 2021

\section{New Discourses on Energy Transition as an Opportunity for Reconciliation? Analyzing Indigenous and Non-Indigenous Communications in Media and Policy Documents}

Carelle Mang-Benza

University of Western Ontario, Canada, cmangben@uwo.ca

Jamie Baxter

University of Western Ontario, Canada, jamie.baxter@uwo.ca

Romayne Smith Fullerton

University of Western Ontario, Canada, romayne.smithfullerton@uwo.ca 


\title{
New Discourses on Energy Transition as an Opportunity for Reconciliation? Analyzing Indigenous and Non-Indigenous Communications in Media and Policy Documents
}

\begin{abstract}
This article examines energy issues articulated by Indigenous and non-Indigenous people in Canada and analyzes the energy transition as a locus of reconciliation therein. Using content and discourse analysis of policy documents, white papers, and news media articles, we draw attention to reconciliation and energy discourses before and after 2015, the year that marked the release of the Truth and Reconciliation Commission of Canada (TRC) report and the Paris Agreement on climate change. After 2015, we find a three-fold expansion of those discourses, which encompass issues of inclusion and exclusion, dependency, and autonomy, as well as colonial representations of Indigenous people,. We also find that non-Indigenous voices are more prominent in those conversations. We suggest that the prospects of mutual benefits could turn the energy transition into an opportunity to bring together Indigenous and non-Indigenous people in Canada.
\end{abstract}

Keywords

Reconciliation, energy transition, discourse analysis, Indigenous people, Canada, policy, media

Creative Commons License (c) $(1) \Theta 9$

This work is licensed under a Creative Commons Attribution-Noncommercial-No Derivative Works 4.0 License. 


\section{New Discourses on Energy Transition as an Opportunity for Reconciliation? Analyzing Indigenous and Non-Indigenous Communications in Media and Policy Documents}

In 2017, the Canadian federal government launched Generation Energy, a country-wide public consultation on the future of the energy sector that involved interactions with over 380,000 Canadians. Among the conclusions, the government website includes the statement: "The energy transition is an opportunity for reconciliation with Indigenous peoples" (Natural Resources Canada [NRCAN], 2018, Our Energy Future section, para. 5). This splicing of energy transition and reconciliation prompted us to explore how a potential new discourse developing along these two national imperatives. The first imperative is reconciliation, which the Canadian federal government has ostensibly embraced as a pathway for addressing colonial legacies, recognizing that colonization undermined Indigenous Peoples' self-determination on their own lands (Adelson, 2005; Kekinusuqs, 2005). The Truth and Reconciliation Commission of Canada (TRC), established to address the legacy of residential schools, defines reconciliation as "establishing and maintaining a mutually respectful relationship between Aboriginal and non-Aboriginal peoples" (Truth and Reconciliation Commission of Canada, 2015, p. 6). The TRC affirms that centuries of colonization severely damaged that relationship and brought adverse social, political, economic, and ecological impacts on Indigenous communities.

The second national imperative is to transition to less carbon-intensive economic activities, especially in the energy sector. An energy transition involves structural changes aiming at "reshaping not only the technologies and economics of energy but also physical and social geographies, social meanings, and the political organization of energy production, distribution, and consumption” (Meadowcroft, 2009, p. 324). According to the Generation Energy report, Canada's energy transition follows two tracks. The first track aims to make the production, distribution, and consumption of energy clean and efficient while the second track is about boosting low-carbon technologies in the oil and gas sector (Generation Energy Council, 2018). The report acknowledges the complexity of navigating this dual-track transition, yet states that it will "involve many and varied energy projects nationwide, and these offer new opportunities to build real, durable partnerships with Indigenous and rural communities by investing directly in their energy future" (Generation Energy Council, 2018, p. 7). For the sake of scoping, we focus specifically on the first track, looking at renewable energy production in the current transition and how it connects to reconciliation. We do so through the lens of public communication.

In their work on decolonization, McFarlane and Schabus (2017) warn that, when the Canadian government and mainstream communication channels acknowledge colonial harms, they often do so while urging us to move on and forget. Indigenous assimilation in a pluralist Canadian society remains the cornerstone of reconciliation in some political agendas. This article probes whether and to what extent there is a melding of discourses of energy transition and reconciliation in public policy documents and select news media - two influential and powerful sources for the propagation of discourses. In this sense, discourse is defined as "an ensemble of ideas, concepts and categories through which meaning is given to social and physical phenomena, and which is produced and reproduced through an identifiable set of practices" (Hajer \& Versteeg, 2005, p. 175). We specifically address two questions: (a) In what ways do Indigenous and non-Indigenous public sources communicate about the energy transition and reconciliation? and (b) How have their communications evolved over time, especially in relation to two landmark moments of 2015: the Paris Agreement on Climate Change and the Final Report of the Truth and Reconciliation Commission of Canada? By comparing published texts from select news media, 
government, and non-governmental organizations, we outline how Indigenous and non-Indigenous voices have been speaking about reconciliation and energy transition in the 2007 to 2018 period, and we consider whether these two groups have been speaking the same language. By bringing insights from Indigenous studies into the energy transition literature, which typically lacks attention to colonial impacts, our work offers a unique contribution to research. This exploration is also relevant for Indigenous and non-Indigenous policy observers as the energy transition is enshrined in federal and provincial governments' plans about carbon pricing, oil and gas, nuclear waste, and renewable energy development. Finally, we hope some of the article's insights might be transferable to other countries bearing a similar history of settler colonialism. In the next section, we provide some context around reconciliation and energy transition to illuminate the ways in which the latter connects to the former. To that end, we begin by describing how colonization damaged the relationship between Indigenous people and settlers and how Indigenous and non-Indigenous people in Canada have been addressing colonial legacies ever since. Next, we introduce how scholars attending to energy and Indigenous issues engage with the involvement of Indigenous communities in renewable energy. Then, subsequent sections outline the analytical approach, summarize the findings, and offer a fulsome discussion.

\section{Context Around Reconciliation and Energy Transition in Canada}

\section{The Problem: Colonization}

The root cause of the broken relationship between Indigenous and non-Indigenous people is colonization, which has had lasting social, political, economic, and ecological impacts on Canada (Adelson, 2005). Between the England-commissioned expedition of John Cabot in 1497 and that of France's Jacques Cartier in 1541, the mandate to identify a route to the Pacific Ocean morphed into a colonization project (Allaire, 2019; Hunter, 2019). Colonization involves the physical movement of an imperialist power across geographical and/or national space to establish domination and supplant the traditional order in a foreign site (Veracini, 2011). Settler colonization is a distinct form of colonization in that, in order to turn the foreign site into a new home, settlers constrain, erase, and extinguish the original inhabitants (Veracini, 2011). Settler colonization "covers its tracks" (Veracini, 2011, p. 3) by engineering structures of dispossession, which in Canada ranged from legislation-for example, the 1857 Gradual Civilization Act and the consolidated 1876 Indian Act - to assimilation projects such as residential schools (Tobias \& Richmond, 2014). Early settlers made extensive and intentional use of binary language to justify, establish, and rationalize a society of deserving "haves" and undeserving "have-nots" (Harding, 2006). In addition, they routinely used racial semantics that condoned the exclusion of Indigenous voices from public life (The National Inquiry into Murdered and Missing Indigenous Women and Girls, 2019a). The vision of the Two Row Wampum belt, used as early as 1613 to document the Treaty between the Haudenosaunee and the Dutch, symbolized as interdependence and independence of both people sharing land and resources, quickly faded away (Hallenbeck, 2015). Settler colonialism dispossessed sovereign Indigenous Nations of their lands and they were methodically pushed to the margins of society (Alfred, 2015). 


\section{Addressing Colonial Legacies: Resurgence and Reconciliation}

There have been numerous attempts to address colonial wrongs that can be broadly encapsulated under the terms "resurgence" and "reconciliation." Resurgence refers to Indigenous people's efforts to assert their identities and reclaim their territories, while reconciliation is perceived as a settler initiative (Asch et al., 2018). The former term acknowledges that Indigenous Peoples were not passive witnesses to the deployment of egregious colonial policies (Canning, 2018). For example, between the 1870s and the 1930s, Indigenous leaders mobilized and engaged in discussions with the federal administration, requesting that the British Crown honor existing treaties (Dyck \& Sadik, 2016; Wilmer, 1993). In the 1940s, Indigenous organizations, such as the North American Indian Brotherhood, entered the public sphere and demanded political recognition (Dyck \& Sadik, 2016). In the 1960s and 1970s, Indigenous Peoples advocated for autonomy and self-determination with regard to health, well-being, Land Rights, and environmental stewardship (Manuel \& Derrickson, 2017; Wilmer, 1993). In the 1980s, Indigenous people used the patriation of the Constitution as an opportunity to safeguard their Traditional Land Titles by enshrining them in what became Section 35 of the Constitution Act (Green, 2003). Through Section 35, Canada recognizes the existence of Indigenous Nations and their practices prior to the arrival of settlers, thus unsettling the colonial project of constraint and erasure of Indigenous Nations (Stanton, 2017).

As highly visible acts of resurgence multiplied, the pressure mounted on the colonial establishment to publicly consider the root causes of the broken relationship between Indigenous and non-Indigenous people in Canada. The wrongful incarceration of a Mi'kmaw youth from the province of Nova Scotia led to the appointment of the Royal Commission on the Donald Marshall Jr. Prosecution in 1986, which exposed the systemic racism plaguing the criminal justice system (Rymhs, 2006). In 1990, a real estate development proposal on land claimed by the Mohawk of Kahnesatake escalated into what became known as the Oka Crisis (Marshall, 2019). Later in 1990, another shockwave ran across the country when First Nations leader Phil Fontaine made stunning revelations about abuses he had experienced in residential school (Nagy, 2014). These events formed the substrate of the Royal Commission on Aboriginal Peoples (RCAP, 1996), tasked to examine the relationships between Indigenous people and the Canadian government and society.

The voluminous RCAP report chipped at the colonial edifice, outlining a pathway to improve the relationship between Indigenous Peoples and settler Canadians, including a recommendation to address one of the most damaging colonial institutions, the residential school system. Parallel to the RCAP public hearings, residential school Survivors launched class action lawsuits supported by the newly elected National Chief of the Assembly of First Nations (AFN), Phil Fontaine (Stanton, 2011). In 2007, they reached the largest class action settlement in national history, the Indian Residential Schools Settlement Agreement (IRSSA), which set aside funding for the establishment of the Truth and Reconciliation Commission of Canada (TRC; Nagy, 2014; Stanton, 2011). The federal government set up the TRC with a five-year mandate to compile the accounts of residential school Survivors into a public record. The TRC chose truth telling as a central feature of its investigation of colonial injustices, and reconciliation as the ultimate goal.

Many aspects of the settler-led reconciliation project are contested: from the concept as a legitimate means to address colonial legacies to the process and outcome. Some Indigenous authors who are 
opposed to the idea of a process framed by colonial structures call reconciliation "the invitation from Canada to share in the spoils of our nations' subjugation and dispossession," a "false promise," and an act of recolonization "telling Indigenous children that the problem of history is fixed" (McFarlane \& Schabus, 2017, p. 11). Coulthard (2010) contended that the political, legal, and economic approaches taken by the State to accommodate Indigenous people always bear the risk of reproducing colonial structures by reconciling "Indigenous claims to nationhood with Crown sovereignty ... in some form of renewed relationship" (p. 6). Reconciliation invites "the dispossessed to see themselves solely as contemporary people, bearing historical (but not contemporary) wounds from misguided State policy that is now remediated by recognition and apology" (Green, 2016, p. 327). Recalling the checkered history of commissions meant to address colonial harms, Rymhs (2006) viewed the TRC process as a "substitute for action" or "discursive balm" (p. 107). Stanton (2011) echoed that perspective, stating "were it not for the enormous financial cost to the government of continuing to defend against the class actions, the TRC would not exist in Canada" (p. 4).

The activists Arthur Manuel and Grand Chief Ronald Derrickson (2017) emphasized restitution of land and resources as the central outcome of true reconciliation, arguing, "anything less than recognizing and affirming Aboriginal rights and treaty rights on the ground is not to seek reconciliation, but surrender" (p. 200). King and Pasternak (2018) analyzed the Indigenous Rights, Recognition and Implementation Framework, announced in early 2018 by the Liberal federal government, and they similarly doubted the effectiveness of legal instruments to bring an acceptable outcome (King \& Pasternak, 2018). They noted that the intended outcome of the legislative transformation under the framework remains unclear, including the fate of the Indian Act and the treatment of Indigenous Title and treaties (King \& Pasternak, 2018).

Other authors, while not oblivious to its inherent risks, are less adamantly opposed to reconciliation. Asch and Borrows (2018) acknowledged the risks of perpetuating colonial patterns in a settler-led initiative; yet they envisioned the possibility that the reconciliation project might lead to real improvements in the lives of Indigenous people. Likewise, Quinn (2011) commended the TRC for making the acknowledgment of wrongs possible, but doubted the inclination of the settler apparatus to substantially address colonial legacies. Some scholars promote a more individual approach to reconciliation. Observing that none of the TRC Calls to Action are addressed to the general public, Ferrara (2015) posited that reconciliation should start with individuals rather than institutions, as a reflexive exercise whereby one would replace colonial dehumanization with "empathic rehumanization" (p. 87). Finegan (2018) referred to such an exercise as "a humbling act," one that asks settlers to "turn a critical eye on themselves and ... relinquish their privilege" (p. 20). Highlighting the inherent challenge to this idea, Chambers (2011) saw reconciliation as a "dangerous opportunity to settler peoples" as it compels them genuinely to examine their "complicity in maintaining the status quo" (p. 260).

While reconciliation is a contested idea, it seems to be taking hold in public narratives. Varied assessments transpire about reconciliation across economic sectors, including in the energy sector-site of recurrent conflicts between Indigenous communities and mainstream energy stakeholders over costs and benefits of extraction activities (Mccreary et al., 2014). The 2017 Generation Energy (2018) report stated that the country wants to "ensure that Indigenous communities benefit more directly from energy development" and that "this transition is an opportunity for Indigenous Peoples and communities to 
take their place at the table and help drive the evolution of Canada's energy sector" (p. 8). We are aware that colonialism in the energy sector has been challenged in Canada through court cases when energy initiatives have threatened Indigenous Rights to Traditional Territories. Unlike the fossil fuel industry, the renewable energy sector is increasingly appealing to Indigenous communities who have a growing presence and influence therein (Campbell, 2011; Cook et al., 2017; Stefanelli et al., 2019). It is to this category of energy projects that we turn next, as we examine the academic literature on energy and Indigenous people.

\section{Energy Transition, Indigenous People, and Reconciliation}

While the Generation Energy report links reconciliation with the energy transition, it is not clear which stakeholders are adopting such terminology. A few authors attend to the motivations of Indigenous communities engaging in renewable energy. These motivations include aspirations to sovereignty, selfdetermination, and financial autonomy, as observed by Lowan-Trudeau (2017) and Ozog (2012). Dreveskracht (2011) noted that renewable energy projects often align with Indigenous values and ways of living on the land but are also opportunities to generate revenues. Karanasios and Parker (2018) argued that Indigenous communities relying on federal financial transfers and land-based employment are increasingly challenged to meet the needs of a growing population with static federal assistance. This combination may motivate Indigenous Nations to engage, on their own or with external partners, in profit-making ventures, including renewable energy production. Karanasios and Parker (2018) also noted that some communities engaged in renewable energy felt tension between sustainable land stewardship and economic development. They had to juggle the urgent concerns of the present generation with the welfare of future generations. Karanasios (2018) quoted Shawn Batise, executive director of the Wabun Tribal Council, who said he values renewable energy projects because "the revenue generated provides a regular flow of income over time, rather than mining, which is over once the ore is depleted" (p.3).

Some authors observed the external and internal barriers constraining Indigenous energy projects. Krupa et al. $(2012,2015)$ asserted that, with perpetual patterns of colonial domination, Indigenous communities must overcome rigid bureaucracy, financial limitations, and even the legacy of mistrust between Indigenous and non-Indigenous stakeholders. Rodman (2013) argued that Indigenous leaders initiating renewable energy projects often face internal resistance when their community opposes the idea of participating in the Western economy, even when the activities are touted as ecological, due to the colonial history of dispossession.

There are only a handful of authors to date who have explicitly connected renewable energy and reconciliation. Jaffar (2015) offered a comparison between narratives of environmentalists and those of Indigenous people. She quoted Former Band Chief Judith Sayers of the Hupačasath First Nation, who "described sustainable energy development as a game changer for First nations" (p. 62). However, Jaffar noted tension rooted in enduring colonial views among environmentalists who often fall into the trap of the "ecological Indian" stereotype. Jaffar concluded that a strengthened alliance between the two groups might propel reconciliation, provided colonial views are addressed. In their review of Indigenous participation in renewable energy, Stefanelli and colleagues (2019) posited that the low-carbon transition provides a dual opportunity for Canada to decarbonize and for Indigenous communities to promote economic development, but stressed the risk of perpetuating colonial injustices. 
Despite analyses of Indigenous communities' involvement in renewable energy, the energy transition literature has not yet integrated the dimensions of colonization in studies of energy systems. This emerging body of literature examines structural changes in energy systems over time. It is organized around three main schools of thought: the technico-economic school stemming from economics and engineering, the socio-technico approach that considers energy as a social phenomenon, and the sociopolitical school that draws on political ecology and political science (Cherp \& Jewell, 2011). To our knowledge, none of these approaches pay explicit attention to Indigenous worldviews. As suggested by Sovacool (2014), energy scholars should be wary of the subtle ways "discourses of energy and climate may erase $[\mathrm{I}]$ ndigenous or alternative forms of knowledge, or hide the particular history or assumptions underlying them" (p. 14). Prompted by the gap in the transition literature and the conclusions of the 2017 Generation Energy consultation, we examined Indigenous and non-Indigenous media and policy communication about renewable energy and reconciliation to understand the evenness (or not) of the uptake of reconciliation discourses in this domain and pinpoint areas of convergence and divergence. Any probe into the energy transition in Canada requires a close look at the provinces since they have primary jurisdiction over their energy systems. While we recognize that one province is not representative of the whole country, we focus on Ontario because it is a leader in the energy sector, and it was also the site of the country's first residential school and is now home to the largest population of First Nations and Métis people in Canada (Carney, 1995; Statistics Canada, 2017).

\section{Methods}

We used content and discourse analysis to explore publicly available statements from both Indigenous and non-Indigenous sources about renewable energy and reconciliation in a selection of media, policy documents, and press releases. We acknowledge that comparing opinion pieces, columns, and news stories with policy papers is challenging because the intents of those documents are different. Nonetheless, together these documents constitute a coherent ensemble of narratives that allow for rich connections and critical interdisciplinary textual analyses drawing from geography, media studies, history, and Indigenous studies.

We also acknowledge that Indigenous authors may publish in mainstream newspapers and that nonIndigenous writers may contribute to Indigenous news pieces. However, we are focused on the origin of the sources more so than the author's identity, recognizing that readership is largely source dependent. That is, we expect that Indigenous readers are the main consumers of Indigenous media and nonIndigenous peoples are more likely to consume mainstream media pieces. Though the lines are permeable, the social reproduction of knowledge through discourse is likely to influence audiences through such alignments. In a settler society, mainstream news media and public policy statements tend to sanction power asymmetry and convey certain representations of the colonized group in their writings (Fullerton \& Patterson, 2008; Harding, 2006). Indigenous sources would generally counter those representations and offer counter narratives on issues of public interest.

Combining content and discourse analysis provides "a critical contrast in representing quantitative and qualitative approaches to the study of textual data" (Tonkiss, 2004, p. 368). It is useful to elucidate the complexity of meanings in language and enrich the exploration of social constructs (Feltham-King \& Macleod, 2016). Content analysis involves counting words or lines and analyzing frequencies of terms, 
allowing for comparison of texts and some level of generalization (Tonkiss, 2004). Discourse analysis is an interpretative study of language in use, which "puts emphasis on the communications through which knowledge is exchanged" and holds the "capacity to illuminate the central role of language in politics" (Hajer \& Versteeg, 2005, pp. 176-177). Speaking to the appeal of discourse analysis in sustainability research, Hajer and Versteeg (2005) added, "the fact that actors debate nature in shared terms does not mean that they understand each other" (p. 177). We posit the same is true here in Canada: Although Indigenous and non-Indigenous people may debate using shared vocabulary, mutual understanding is not guaranteed.

We defined our analysis timeframe to account for significant events related to renewable energy and reconciliation in the country and in Ontario specifically. We selected the window between January 1, 2007, and June 30, 2018, a period that starts two years before the Ontario Green Energy and Green Economy Act (2009), includes the TRC's (2015) final report and Paris Agreement on climate change, and ends two years after the Pan-Canadian Framework on Clean Growth and Climate Change (Government of Canada, 2016). The 2009 Green Energy and Green Economy Act, now repealed, was a significant piece of legislation because it boosted renewable energy production in Ontario and provided premium electricity tariffs to projects with Indigenous participation. The 2016 Pan-Canadian Framework, a statement of national ambition on climate change, was adopted alongside representatives of First Nations, Inuit, and Métis peoples as one of the post-TRC symbols of Canada's commitment to engage with Indigenous Peoples in the low-carbon transition and natural resource management. Though the impacts of the TRC and the Paris Agreement will not be fully understood for several years, our goal is to take stock of the current trajectory.

In order to capture what Indigenous and non-Indigenous sources say about renewable energy and reconciliation, we looked into news media, reports, and documents from political institutions. Using the Indigenous studies websites of the University of British Columbia (n.d.) and Dalhousie University (n.d.) of Nova Scotia, we identified Indigenous newspapers with both national (e.g., First Nations Drum, Windspeaker) and provincial or regional coverage (e.g., Alberta Sweetgrass, Saskatchewan Sage, Wawatay News covering Ontario First Nations, Nunatsiaq News in Nunavut). We also gathered documents from three political organizations, namely the AFN, Inuit Tapiriit Kanatami, and the Chiefs of Ontario. We used these organizations as proxies for Indigenous policy makers because they represent a large number of Indigenous communities and take part in political debates. The AFN represents most First Nation communities in Canada (White et al., 2012); Inuit Tapiriit Kanatami (ITK) advances the rights of Inuit communities, while the Chiefs of Ontario advocate for issues relevant to First Nations in the province. We used the corporate press releases from their websites as statements of their political stances. We did not include any Métis organizations because there was insufficient data at the time of analysis.

Among non-Indigenous sources, we examined four categories of documents: news media articles, reports and position papers, policy papers, and bills. We collected news media pieces from the "Canadian major dailies" database to retrieve newspapers from as many provinces as possible. The reports and position papers were taken from the 97 submissions to the Generation Energy consultation (Natural Resources Canada, n.d.). We discarded submissions that did not reference Indigenous communities and those that did not focus on renewable energy. Policy papers came from the federal and 
provincial (Ontario) governments and bills from the Legislative Assembly of Ontario. We selected policy documents and bills with a direct relation to energy policy.

We searched the website of each Indigenous source using the following strings: "renewable energy," "clean energy," and "reconciliation." We added the terms "Indigenous OR Aboriginal" in searching nonIndigenous news media. We also used French equivalent terms: "autochtone" AND "énergie renouvelable," and "énergie" AND "reconciliation." Our final data set is described below and presented in more detail in Table 1.

\section{Findings}

\section{Content Analysis}

Based on a first reading of the documents, we derived the themes of autonomy, inclusion, exclusion, and economic development. We then reviewed each document line by line and inductively added emerging themes using the NVivo software (Version 12). At the end of the analysis, we had a list of six main themes, 21 sub-themes, and 1,501 sections of text (hereafter referred to as statements) coded under the various themes. Table 2 displays the number of occurrences of each theme, namely inclusion, dependency, representations of Indigenous assets, exclusion, autonomy, and Indigenous people as afterthought, by time period and source. The theme inclusion points to various ways of bringing together Indigenous and non-Indigenous people in Canada, including through energy development, climate change, economic development, land access, and cultural exchange. Statements of dependencydescribe Indigenous people as needing support, as vulnerable people, and even as liabilities for Canada in energy development. Representations of Indigenous assets depict Indigenous people as political voices, business partners, holders of valuable knowledge, stewards of the land, workforce, and political stooges. The sub-theme of political stooges carries negative connotations related to political gaming. It was attributed to quotes conveying the impression that the federal government feigned concern for Indigenous Peoples in search of good press, international recognition, or stability for corporate actors. The theme of exclusion refers either to language of opposition that positions Indigenous people and non-Indigenous people as antagonists, or to language of negation that disregards any difference between the two, casting the colonial legacy into oblivion. Autonomyinvolves Indigenous control over land and economic development. Finally, we attributed the theme of Indigenous people as after-thought to statements based on either the position of a mention to Indigenous people (e.g., at the end of a paragraph) or the apparent importance of a particular mention.

The post- or pre-TRC ratio is an indicator of the frequency of those themes before and from 2015 . The non-Indigenous to Indigenous ratio indicates the number of statements from non-Indigenous sources relative to Indigenous sources under each theme. Table 3 presents the 21 sub-themes composing the six main themes. As visual illustrations of our findings, Figure 1 compares the occurrence of the six themes in Indigenous and non-Indigenous sources while Figure 2 illustrates the evolution of those themes before and after 2015 . 
Table 1. Overview of Documents Included in the Data Set

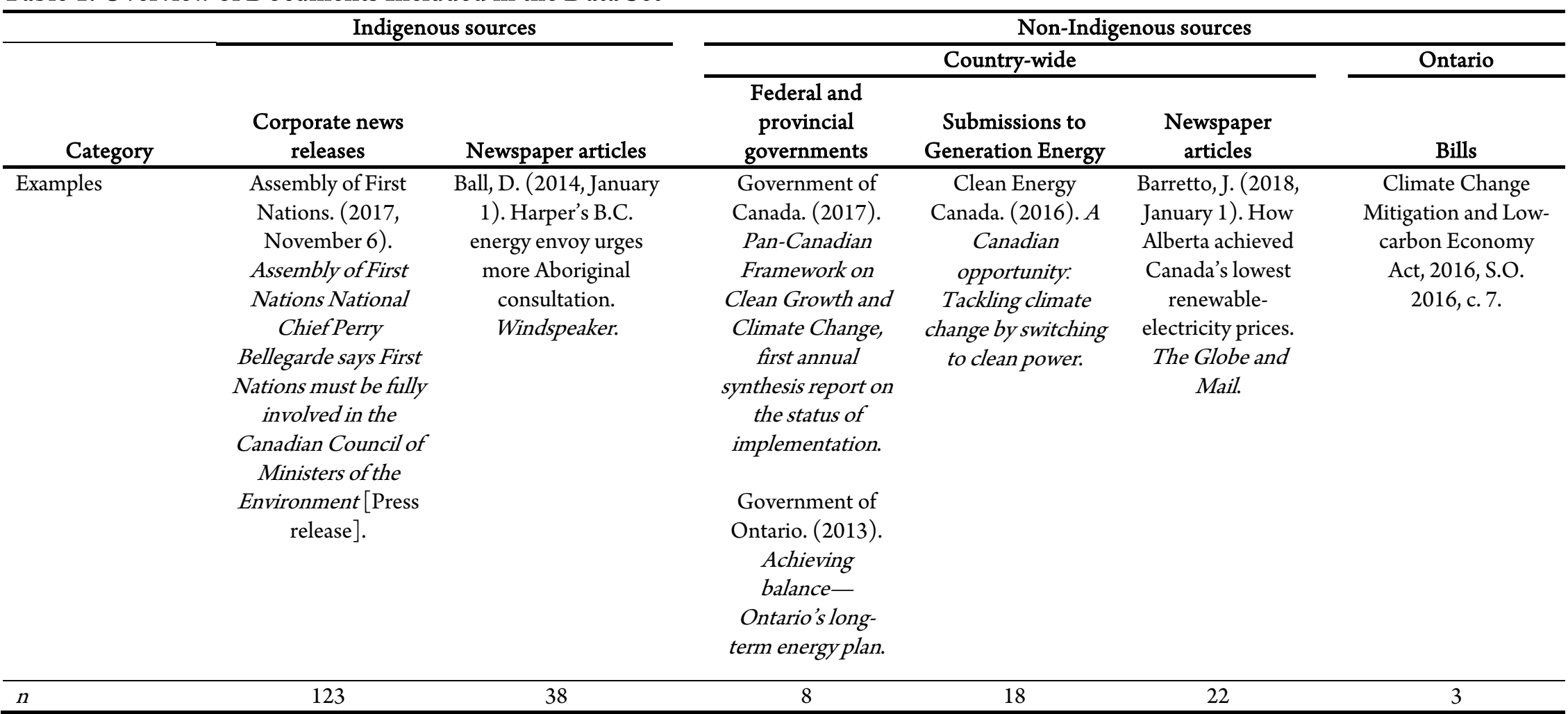

Note. $N=212$ 
Table 2. Distribution of Themes Between Indigenous and Non-Indigenous Sources Before and After the TRC Report

\begin{tabular}{|c|c|c|c|c|c|c|c|}
\hline \multirow[b]{2}{*}{ Themes } & \multirow[b]{2}{*}{$\begin{array}{l}\text { Number of } \\
\text { statements } \\
\text { per theme }\end{array}$} & \multicolumn{2}{|c|}{ Pre-TRC (2009-2014) } & \multicolumn{2}{|c|}{ Post-TRC (2015-2018) } & \multicolumn{2}{|c|}{ Ratios } \\
\hline & & $\begin{array}{c}\text { Indigenous } \\
\text { sources } \\
(\%)^{a}\end{array}$ & $\begin{array}{c}\text { Non- } \\
\text { Indigenous } \\
\text { sources } \\
(\%)^{\mathrm{a}} \\
\end{array}$ & $\begin{array}{c}\text { Indigenous } \\
\text { sources } \\
(\%)^{\mathrm{a}}\end{array}$ & $\begin{array}{c}\text { Non- } \\
\text { Indigenous } \\
\text { sources } \\
(\%)^{\mathrm{a}} \\
\end{array}$ & $\begin{array}{c}\text { Post/pre } \\
\text { TRC }\end{array}$ & $\begin{array}{c}\text { Total } \\
\text { non-Indigenous } \\
\text { statements/ } \\
\text { total Indigenous } \\
\text { statements } \\
\end{array}$ \\
\hline Inclusion & 484 & $8 \%$ & $9 \%$ & $29 \%$ & $54 \%$ & 4.8 & 1.7 \\
\hline Dependency & 291 & $9 \%$ & $15 \%$ & $20 \%$ & $56 \%$ & 3.2 & 2.4 \\
\hline $\begin{array}{l}\text { Representations } \\
\text { of Indigenous } \\
\text { assets }\end{array}$ & 265 & $13 \%$ & $12 \%$ & $26 \%$ & $49 \%$ & 3.0 & 1.6 \\
\hline Exclusion & 258 & $16 \%$ & $23 \%$ & $31 \%$ & $30 \%$ & 1.6 & 1.2 \\
\hline Autonomy & 161 & $11 \%$ & $19 \%$ & $32 \%$ & $39 \%$ & 2.4 & 1.3 \\
\hline $\begin{array}{l}\text { Indigenous } \\
\text { Peoples as after- } \\
\text { thought }\end{array}$ & 42 & $0 \%$ & $33 \%$ & $5 \%$ & $62 \%$ & 2.0 & 20.0 \\
\hline $\begin{array}{l}\text { Total number } \\
\text { of coded } \\
\text { statements }\end{array}$ & 1,501 & 159 & 224 & 401 & 717 & 2.9 & 1.7 \\
\hline
\end{tabular}

Note. ${ }^{\text {a }}$ Percentages pertain to the themes in each row. 
Table 3. Distribution of Sub-Themes Under Each Theme Over the Study Period 2007-2018

\begin{tabular}{|c|c|c|c|c|c|}
\hline $\begin{array}{l}\text { Main } \\
\text { themes }\end{array}$ & Inclusion & Dependency & $\begin{array}{l}\text { Representations of } \\
\text { Indigenous people }\end{array}$ & Exclusion & Autonomy \\
\hline \multirow[t]{6}{*}{ Sub-themes } & $\begin{array}{l}\text { Inclusion through energy } \\
(48 \%)\end{array}$ & $\begin{array}{c}\text { Indigenous Peoples } \\
\text { need support } \\
(53 \%)\end{array}$ & $\begin{array}{c}\text { Indigenous Peoples as } \\
\text { political voice } \\
(34 \%)\end{array}$ & $\begin{array}{c}\text { Discourse of opposition } \\
\text { and separation } \\
(41 \%)\end{array}$ & $\begin{array}{l}\text { Autonomy through land } \\
(44 \%)\end{array}$ \\
\hline & $\begin{array}{c}\text { Together against climate } \\
\text { change } \\
(18 \%)\end{array}$ & $\begin{array}{l}\text { Indigenous Peoples are } \\
\text { vulnerable } \\
(43 \%)\end{array}$ & $\begin{array}{l}\text { Indigenous Peoples as } \\
\text { business partners } \\
(28 \%)\end{array}$ & $\begin{array}{l}\text { Opposition related to } \\
\text { energy issues } \\
(37 \%)\end{array}$ & $\begin{array}{c}\text { Autonomy through } \\
\text { economic development } \\
(40 \%)\end{array}$ \\
\hline & $\begin{array}{l}\text { Meaning of reconciliation } \\
\qquad(18 \%)\end{array}$ & $\begin{array}{c}\text { Indigenous Peoples as } \\
\text { liabilities } \\
(4 \%)\end{array}$ & $\begin{array}{l}\text { Indigenous Knowledge as } \\
\text { valuable for Canada } \\
(16 \%)\end{array}$ & $\begin{array}{l}\text { Discourse of negation } \\
\qquad(22 \%)\end{array}$ & $\begin{array}{c}\text { Autonomy } \\
\text { through equity } \\
(16 \%)\end{array}$ \\
\hline & $\begin{array}{c}\text { Inclusion through } \\
\text { economic development } \\
(11 \%)\end{array}$ & & $\begin{array}{l}\text { Indigenous Peoples as } \\
\text { stewards of the land } \\
(15 \%)\end{array}$ & & \\
\hline & $\begin{array}{l}\text { Inclusion through } \\
\text { land use } \\
(4 \%)\end{array}$ & & $\begin{array}{l}\text { Indigenous Peoples as } \\
\text { workforce } \\
(5 \%)\end{array}$ & & \\
\hline & $\begin{array}{l}\text { Inclusion through } \\
\text { cultural exchange } \\
(1 \%)\end{array}$ & & $\begin{array}{c}\text { Indigenous Peoples as } \\
\text { political stooges } \\
(2 \%)\end{array}$ & & \\
\hline
\end{tabular}

Note. The theme Indigenous Peoples as after-thought has no sub-theme. 
Figure 1. Comparison of Themes in Indigenous and Non-Indigenous Sources

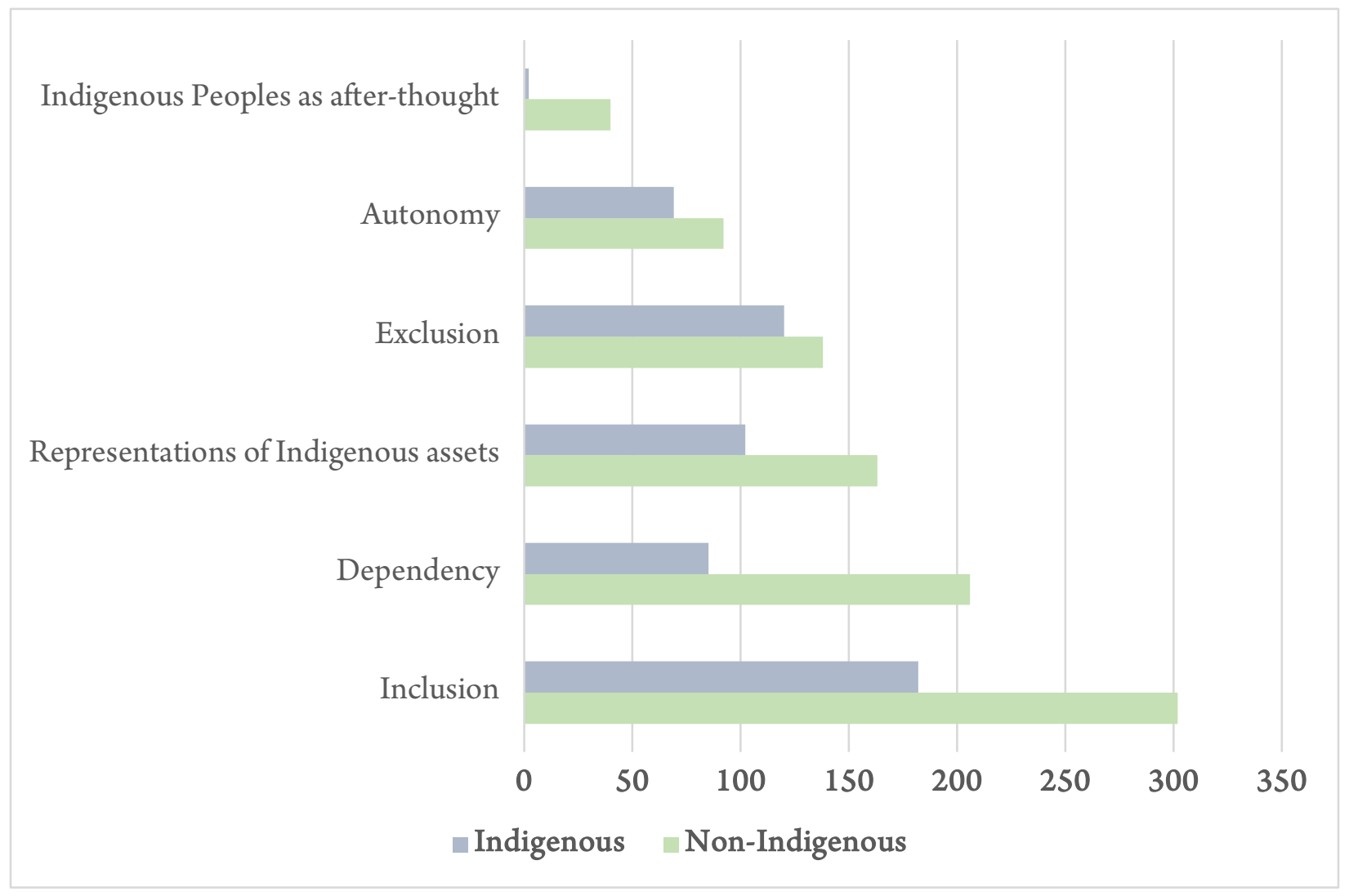


Figure 2. Occurrence of Themes Before and After 2015

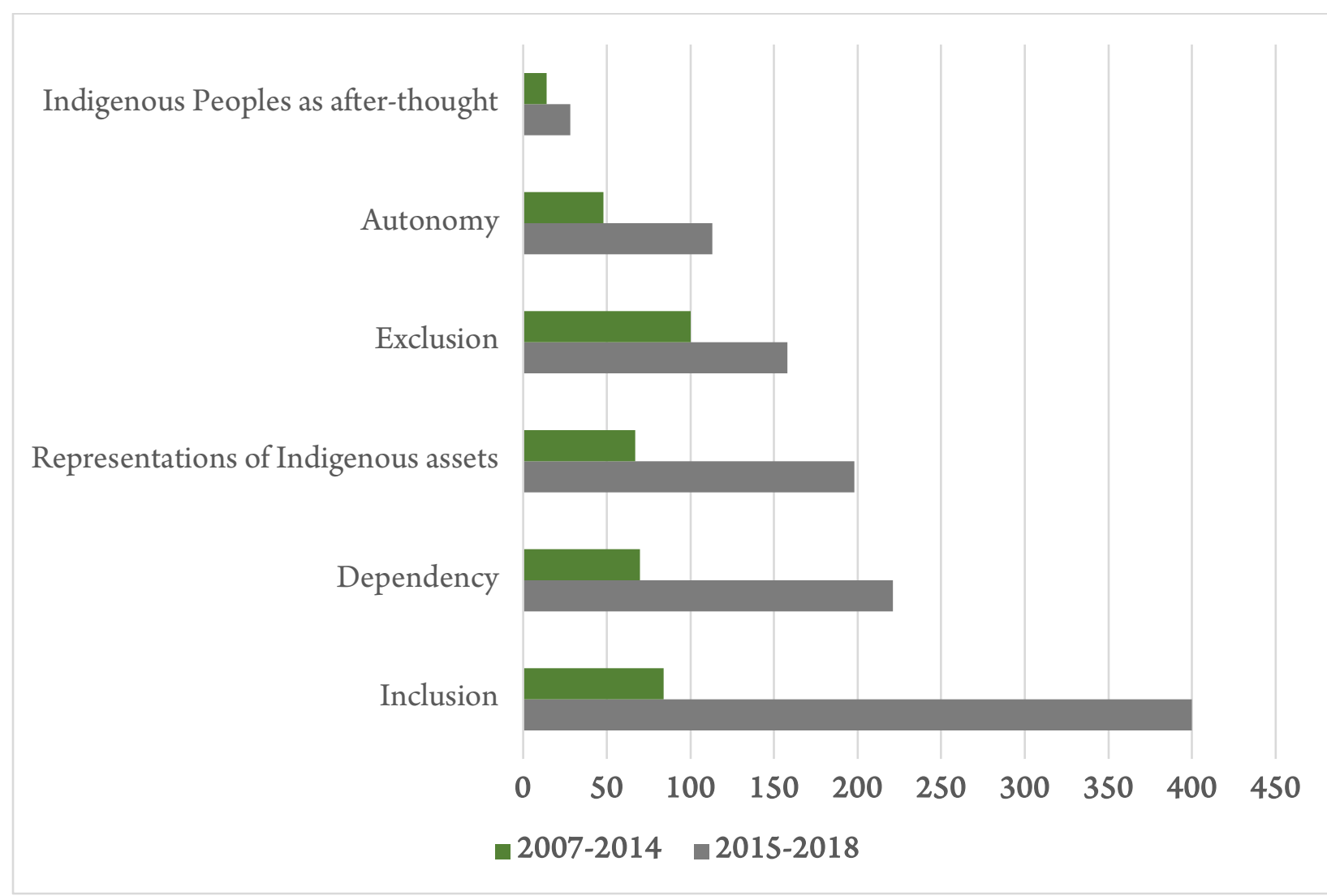

Temporally, Table 2 and Figure 2 show that all themes have become more prevalent post-TRC, while at the extremes, the theme of inclusion has increased the most ( 4.8 times), while the theme of exclusion has expanded the least 1.6 times). While the move away from exclusion towards inclusion suggests an improvement of relationships, other aspects point to serious disconnects. Non-Indigenous voices dominate all themes, which may be an artefact of the data collection strategy. It can also reflect the fact that non-Indigenous media are ubiquitous and Indigenous voices have historically been absent and continue to be underrepresented in mainstream media.

\section{Discourse Analysis}

Now we provide a qualitative analysis of each theme, navigating between types of document to show how the same themes are reproduced in various public spaces and how those spaces echo and respond to each other. 


\section{Inclusion}

This is by far the most prominent theme, with 484 supporting statements, originating mainly from nonIndigenous sources. The theme increased almost 4-fold after the TRC, which suggests that the settler sources are increasingly diffusing messages about energy development in Indigenous communities. Table 3 shows that, out of the six sub-themes pertaining to inclusion, the three most common are inclusion through energy, meanings of reconciliation, and together against climate change. The nuances in the statements also matter: Indigenous and non-Indigenous sources do not speak to the same themes in the same way nor for the same reasons. For example, in the following statement coded under the theme inclusion through energy, AFN Chief Bellegarde spoke to full involvement of Indigenous people as essential for meaningful reforms in energy decision-making processes. This view aligns with the resurgence approach that challenges colonial structures.

National Chief Bellegarde also urged Premiers to ensure First Nations are fully included in the development of any National Energy Strategy, stating that regulatory approvals for major projects will only truly be reformed and improved if First Nations are fully involved. (AFN, 2015b, para. 5)

Non-Indigenous communication about inclusion through energy sounds less adamant. The following statement from the first synthesis report of the Pan-Canadian Framework on Clean Growth and Climate Change presents provincial initiatives on renewable energy benefiting Indigenous and non-Indigenous communities:
Alberta proclaimed the Renewable Electricity Act and launched the Renewable Electricity program to support the development of 5,000 megawatts of renewable electricity capacity by 2030. The province also announced $\$ 35$ million to fund Indigenous climate leadership initiatives, including renewable and solar energy projects in First Nation and Metis communities. (Government of Canada, 2017, p. 7)

Without using the word "reconciliation," the above excerpt sits well with Western imaginaries of a pluralist society awarding equal opportunities to all, oblivious to the fact that many Indigenous communities struggle with technical capacities to develop projects and are still constrained by Indian Act provisions regarding on-reserve investments. For these communities, the mere existence of a climate fund is not sufficient to overcome the structural barriers to resource development. Indigenous voices demand a form of inclusion that confronts the inertia of colonial structures. The newspaper Anishinabek News reports comments made by Cynthia Wesley-Esquimaux, chair of Truth and Reconciliation at Lakehead University in Ontario, in which she calls for concrete action, demanding that Indigenous people gain authority and decision-making power (Garrick, 2017).

The Indian residential schools became an industry, reconciliation is becoming an industry, everything we touch turns to gold. Except it never touches us, and that is really the biggest issue that we have... You need to hire Indigenous people in administrative positions where they have the authority to make decisions and actually implement change. If you do not do that, you are not doing your job and you are not doing reconciliation. (Garrick, 2017, para. 2) 
Within these sources, Indigenous people were not ready to pare down their demands to have a meaningful role in discussions and at decision-making tables. They wanted equitable sharing of benefits in resource development. Indigenous people who subscribe to the idea of inclusion seek to veer away from old ways of thinking and doing. However, those old ways persist, as illustrated by the discourse of dependency found in many forms of public communications.

\section{Dependency}

This theme covers 291 sections of text in our data set, about 1 in 5 , as shown in Table 3 . The sources mainly originate from non-Indigenous media and also significantly increased after 2015. One of the common themes relates to living conditions among Indigenous people and their perceived vulnerability to climate change, as reflected in the following quote from the Pan-Canadian Framework on Clean Growth and Climate Change (2016).

Indigenous Peoples, northern and coastal regions and communities in Canada are particularly vulnerable and disproportionately affected. Geographic location, socio-economic challenges, and for Indigenous Peoples, the reliance on wild food sources, often converge with climate change to put pressure on these communities. (Government of Canada, 2016, p. 1)

Indigenous leaders, like National Chief of the AFN Perry Bellegarde also use the language of dependency, but from a different standpoint. In the following excerpt from an AFN news release, Bellegarde reminds the federal government of its financial obligations and its historic role in institutionalizing Indigenous poverty and dependency as part of his demand for fundamental change.

There are two basic problems: first the status quo of chronic, conscious underfunding regardless of need or equity; and second, First Nations governments are funded like NGOs rather than governments that are part of the constitutional fabric of this country. (AFN, 2015a, p. 4)

Under the theme of dependency, a small number of excerpts refer to Indigenous people as liabilities, often in a very subtle way. A 2013 newspaper article from La Presse (Baril \& Journet, 2013), a major daily in Quebec, reported mixed reactions among energy stakeholders in the province following the release of market allocations to wind energy producers, including Indigenous producers. The news article subtly weaves together public discontent over rising electricity costs and a complaint that an overaccommodating process allocated generous energy production contracts ( 150 of the total $800 \mathrm{MW}$ production capacity) to Mi'gmaq communities. Words such as "aberration" (non-sense), "déploré" (lamented), and "déçü" (disappointed) stand out because these sentiments directed toward Indigenous people, though few, speak loudly to the enduring patterns within the settler mentality. Thankfully, alternative representations of Indigenous people were also found within public communications, a hopeful sign of changing times.

\section{Indigenous Representations}

This third theme, with 265 statements, tripled after the TRC. Until 2014, we found an almost equal number of Indigenous representations in Indigenous and non-Indigenous sources (see Table 2). From 2015 onward, non-Indigenous voices dominate this category, which could point to the TRC's impact on a nation suddenly more aware of patterns that historically besmirched Indigenous people and now 
seeking to make amends. The occurrences of the sub-theme Indigenous people as political voices could also be indicative of a shifting power dynamic. The following statement from the 2013 Long-Term Energy Plan of Ontario reflects the role of Indigenous people as business partners in the energy sector (Government of Ontario, 2013):

The Ring of Fire, $540 \mathrm{~km}$ northeast of Thunder Bay, has the potential to become a significant economic development driver for Northern Ontario and First Nation communities. To help realize this potential, Ontario has announced its intention to partner with industry, First Nations and the federal government to create an infrastructure development corporation. (Government of Ontario, 2013, p. 49)

The recognition of Indigenous communities as business partners is necessitated by the abundance of natural resources on Traditional Lands. This idea connects to the marginal sub-theme of political stooges, representing a small $2 \%$ of the statements categorized as Indigenous representations. The political stooge representation, though very rare, is nevertheless problematic because it could indicate that Indigenous people's voices are included in substantial policy discussions in a tokenistic manner. This sub-theme carries the negative connotation of political gaming, conveying the impression that Indigenous people might be stooges to the federal government in search of good press, international recognition, or stability for corporate actors. The very small but continued prevalence of the political stooge representation is problematic because it likely will persist if Indigenous people's voices are excluded from substantial policy discussions.

\section{Exclusion}

The theme of exclusion represents 258 of the 1,501 statements, or 1 in 6 . The following excerpt, taken from a submission from the University of Ottawa to the Generation Energy consultation, sets the tone of the energy-reconciliation conversation in the post-TRC era, stressing its challenges and the likelihood of controversial outcomes.

First of all, big unresolved policy_-decarbonisation and reconciliation with Canada's Indigenous peoples - will not be solved by institutional changes. It will still be chaotic, politically messy and expensive. It will require human resource capabilities far greater than Canada devotes today to managing energy policy and regulation. Decisions eventually have to be made and there will be winners and losers. (Cleland \& Gattinger, 2017, p. 38)

Cleland et al. (2017) recognize the limitations of institutions in addressing the joint imperatives of energy transition and reconciliation and draw attention to Canada's "underlying value conflicts and divergent interests left unresolved" (p. 4). Their reference to divergent interests is premised on a 2015 national survey that illustrates the challenges of decarbonisation and reconciliation. To a question about support to "Canadian governments working to negotiate an energy accord with Canada's Aboriginal peoples to reduce conflict and uncertainty in the development of energy projects" (University of Ottawa 2015 , p. 4), 49\% of the survey participants responded that they would support such negotiations and $32 \%$ that they would somewhat support them. Such response evinces a general placatory attitude towards Indigenous people. However, when asked, "What is more important in a proposed energy 
project moving forward?," $54 \%$ of respondents selected the national interest while $36 \%$ prioritized the rights of Indigenous people:

Overall Canadians generally believe that it is possible to develop resources while protecting the environment and are supportive of investments in the renewable energy sector. They also clearly expect the federal government to take the lead and think the national interest is more important than local, provincial or Aboriginal views. (University of Ottawa, 2015, p. 2)

The very formulation of the survey question could put respondents in a mindset of dichotomous choice between energy and reconciliation. This survey construction is revealing as it suggests the dilemmas that Canadians face at the crossroads of energy transition and reconciliation. At that crossroads also lies the issue of Indigenous autonomy.

\section{Autonomy}

We coded just over 1 in 10 excerpts (161 out of 1,501 in Table 2) under the autonomytheme and found statements originate from non-Indigenous voices almost as often as from Indigenous voices (ratio of 1.3). However, when these two demographics talk about autonomy, they do not mean the same thing. In its 2017 Long Term Energy Plan, the Government of Ontario (2017) provided several examples of what it calls Indigenous leadership in the energy sector:

In June 2017, the Wikwemikong First Nation launched its Ignite Energy and Infrastructure Project. . . It is estimated this will save the community more than $\$ 157,000$ per year in energy costs, a 58 per cent savings in the energy used for lighting. The $\$ 1.1$ million project will be financed with a contribution of $\$ 127,900$ from the IESO's Save on Energy Program and private debt financing. (p. 131)

In the following excerpt from a newspaper article published in Anishinabek News, Chief Denise Restoule of Dokis First Nation in Ontario conveyed her pride in her community's engagement in hydroelectric development and assertion of political autonomy:

She pointed out that Dokis was proud to contribute to creating green energy and assisting in climate change while world leaders were discussing this topic and challenged Canadians to recognize the importance of environmental stewardship...

Dokis First Nation membership voted to opt out of the sections of the Indian Act dealing with land issues and ratified their own land code in 2013. By ratifying their own Land Code, Dokis membership took a bold step to manage their own lands, resources and environment as enabled through the First Nations Land Management Act. (cited in Krackle, 2015, paras. 2 \& 7 )

Behind the ecological engagement of Dokis First Nation is a bold assertion of autonomy. The Dokis First Nation went beyond merely implementing an energy project; instead, they ratified their own land code outside of the Indian Act. This granted them a seat at the decision-making table in a new government-to-government relationship. Speaking about closing the development gap between Indigenous and non-Indigenous communities, National Chief Perry Bellegarde demanded a new form of relationship:

Published by Scholarship@Western, 2021 
We are not a third order of government or a municipal form of government ... Shared sovereignty means we will no longer tolerate being treated as "claimants" in our own lands. What we hold is what the Creator gave us. We do not hold "grievances," we hold this land ... We are resuming control. We are re-asserting jurisdiction over our lands and resources ... First Nations are no longer willing to sit on the side of the road watching rocks, minerals, forests, and other natural resources taken from our territories while our communities struggle. (AFN, 2015a, p. 8)

The notion of "third order" connects with the theme of after-thought, a position in public debates that Indigenous communities adamantly reject.

\section{After-Thought}

Relatively few statements, only 42, were coded under this theme. Two of them were taken from Indigenous newspapers reporting government action and the others from non-Indigenous sources. The following excerpt taken from a white paper submitted to the Generation Energy consultation fits in the former category. It focuses on the intergovernmental policy space on climate change and energy, describing areas of collaboration between federal, provincial, and territorial jurisdictions.

The federal government cannot own a comprehensive Canadian energy strategy; the provincial and territorial governments are too constitutionally empowered and too important practically to be overlooked ... The challenge is to find a strategic language that acknowledges both the autonomy and co-dependence of the federal and provincial governments, and for that matter, municipal and Indigenous governments. (Gibbins, 2017, p. 15)

The context of this statement is the jurisdictional split on energy issues among federal, provincial, and territorial governments, a constitutional challenge that is compounded when discussions extend to Indigenous governments. The excerpt lists the provincial and territorial governments as entities too important to be overlooked, while Indigenous governments are listed at the end of the paragraph, alongside municipal governments. The following example, taken from Ontario's Climate Change Action Plan for 2016-2020, illustrates an inherent contradiction between stated political intent of a program and actual program content:

Action Area: Collaboration with Indigenous Communities Action

Intended GGRA Funding (Total): $\$ 85,000,000$ to $\$ 96,000,000$

Est. GHG Reduction In 2020*: TBD

Est. Cost Per Tonne: TBD

Timetable Action Start: 2017/18 (Government of Ontario, 2016, p. 73)

This text was taken from a section on collaboration with Indigenous communities; it consists of two rows at the bottom of a page, between two pages on collaboration with industry and business and two pages about research and development. The section outlines in detail the challenges and opportunities 
attached to the collaboration with Indigenous communities; however, the quantitative tables corresponding to the narrative send a different message. As we note, there is a stated funding allocation, but no estimate of the greenhouse gas emission reduction nor estimated cost of action. With many of the attributes of a recipe for failure, the government's plan of action encapsulates the idea of Indigenous people as an after-thought. There are few such examples in our data set, but the ones there are do illustrate the ingrained patterns of thinking in settler society and policy circles. We elaborate in the following section the implications of our findings.

\section{Discussion and Conclusion}

We examined the ways in which Indigenous and non-Indigenous sources communicate about reconciliation within the energy transition to understand if reconciliation is accepted as a concept, by whom, and with what potential effect. Our findings show antithetical issues of inclusion and exclusion, and of autonomy and dependency, interlaced in public communications. Overall, non-Indigenous voices dominate those communications where empowering representations of Indigenous people coexist alongside prejudiced ones. The texts examined rarely reflect the differences in Indigenous and Western imaginaries about development and well-being, which is symptomatic of Canada's historical context where, even when Indigenous voices and views are included in news media, they are "diluted through techniques of deflection, decontextualization, misrepresentation and tokenization" (Harding, 2006, p. 225). One of the common tropes noted by Harding (2006), "[A]boriginal as victim" (p. 225), is reflected in our findings through themes such as Indigenous people need support and Indigenous people are vulnerable, with both tropes recurring in non-Indigenous communications.

In contrast, discourses of autonomy and exclusion are only slightly dominated by non-Indigenous voices. This may indicate that both Indigenous and non-Indigenous Canadians similarly aspire to see higher levels of Indigenous autonomy, even though autonomy may take on different meanings for each group. For settlers, Indigenous autonomy may mean equality, an "inherent feature of liberal democracy" (Alfred, 2011, p. 167), which does not grant special treatment to any category of people. The national survey cited earlier indicates that settlers are not ready to sacrifice their interests to benefit Indigenous people (University of Ottawa, 2015). This perspective gives credence to Indigenous critics who argue that the underlying intention of reconciliation is to maintain the status quo (Alfred, 2015) and that settlers are willing only to accommodate Indigenous claims that do not threaten colonial privileges (Davine et al., 2017; Lowan-Trudeau, 2017). Our analysis also illustrates that resurgence is alive and well, as evidenced by examples of Indigenous people refusing to bend to colonial pressures. One such instance is Inuit leadership engaging in a "David and Goliath style communication struggle" (Inuit Tapiriit Kanatami, 2015, para. 52) to confront the Eurocentric imaginaries of life in the Arctic and assert their rights to traditional hunting practices.

In connection to our second question about the evolution of discourses between 2009 and 2018, we highlighted the significant expansion of the theme inclusion that brings together Indigenous and nonIndigenous people in Canada and the marginal expansion of the theme exclusion that juxtaposes the two groups as antagonists. This finding suggests that Indigenous and non-Indigenous people increasingly discuss the convergence of reconciliation and decarbonisation imperatives as they both share significant interest in the development of energy resources (Dreveskracht, 2011; Krupa, 2012). However, the shared interest in the energy sector may not be sufficient to topple the colonial edifice because 
"something was stolen, lies were told and they have never been made right" (Alfred, 2011, p. 166). This is one of the reasons why Indigenous leaders insist on fully participating in energy decision-making processes in the post-TRC era.

In direct response to the Generation Energy statement, we posit that there is neither evidence nor guarantee that the current energy transition will improve the relationship between Indigenous and nonIndigenous people. At its worst, it may sustain the status quo by reinforcing current colonial structures. At the same time, rather than utterly discarding the conclusions of the Generation Energy consultation, we argue that there is a possibility of cross-fertilization between the energy transition and reconciliation journeys. On the one hand, the energy transition could improve relationships by forcing settler society to address unresolved issues related to Indigenous lands and resource development. Building on this idea, the theme together against climate change is the second most prominent theme under the inclusion discourse. Fighting climate change is a national imperative and also ranks at the top of priorities listed in the document, Honouring Promises, released by the AFN (2019) ahead of the 2019 federal elections. The AFN priorities were quickly endorsed by the Green Party of Canada (2019), which also pledged to put in place a framework for Indigenous people to opt out of the "racist and oppressive" Indian Act as part of their reconciliation strategy (para. 3). However, some observers note that opting out of the Indian Act does not appear on the AFN list of priorities, and this is an indication that consensus on climate change may hide divergent views on the format and outcome of reconciliation.

On the other hand, the reconciliation journey could provide an opportunity to revisit energy transition pathways by bringing Indigenous worldviews in energy debates, including Canada's conversation on a dual-track energy transition aiming for both clean energy production and low-carbon oil and gas production. Asch and Borrows (2018), alluding to a form of ecological reconciliation, underscored the unique relationship that Indigenous people have with the water, wind, sun, rocks, and land. This perspective is also reflected in our findings through the sub-theme related to Indigenous people as land stewards. They make it clear that, while Indigenous people are neither inherently more ecologically focused, nor more destructive to the environment, yet Indigenous people generally hold in respect the notion of natural "inherent limits." This is a notion with which Eurocentric societies still struggle to align and if energy transition is to succeed, it is an approach that is much needed.

We argue, alongside Senator Murray Sinclair, that Canada might be "on the cusp of something special" as it gradually shakes its colonial "cloak of pain and shame" (cited in McFarlane \& Schabus, 2017, p. 71) while dealing with its fossil fuel addiction. In 2008, speaking at the United Nations Climate Conference in Poland, the federal Environment Minister stated that the United Nations Declaration on the Rights of Indigenous Peoples (UNDRIP) had "nothing whatsoever to do with climate change" (cited in Curry \& Mittelstaedt, 2008). The political messaging has evolved a great deal since then. In direct response to the TRC Calls to Action, Canada fully adopted UNDRIP in 2016, which opened new opportunities for Indigenous people in Canada to voice their positions about natural resource development and climate change. The TRC report also provided the foundation for the National Inquiry into Missing and Murdered Indigenous Women and Girls (MMIWG, 2019b), which in its final report outlines 231 Calls for Justice, includes an executive summary in an Indigenous language (Inuktitut), and provides a legal analysis on colonial genocide. As these and other accounts of colonial harms and injustices come to the 
surface, they bring opportunities to renegotiate the relationship between Indigenous and nonIndigenous people in Canada in more fundamental ways than the contested "apologize-and-beabsolved" approach to reconciliation (Alfred, 2011, p. 167). Therein resides the opportunity to reduce both carbon emissions and entrenched colonial patterns by engaging in an energy transition that does not name winners and losers along racial lines. As the concept of reconciliation is challenged and evolves over time, there might appear opportunities to rise to the vision of the Two Row Wampum.

\section{References}

Adelson, N. (2005). The embodiment of inequity health disparities in Aboriginal Canada. Canadian Journal of Public Health, 96, 545-561. https://doi.org/10.1007/BF03403702

Alfred, T. (2011). Restitution is the real pathway for justice of Indigenous Peoples. In G. Younging, J. Dewar, \& M. DeGagné (Eds.), Response, responsibility, and renewal: Canada's truth and reconciliation journey (pp. 163-170). Aboriginal Healing Foundation.

Alfred, T. (2015). Cultural strength: Restoring the place of Indigenous Knowledge in practice and policy. Australian Aboriginal Studies, 1, 3-11.

Allaire, B. (2019). Jacques Cartier. The Canadian Encyclopedia. https://www.thecanadian encyclopedia.ca/en/article/jacques-cartier

Asch, M., Borrows, J., \& Tully, J. (2018). Resurgence and reconciliation: Indigenous-settler relations and earth teachings. University of Toronto Press. https://doi.org/10.3138/9781487519926

Assembly of First Nations (AFN). (2015a, April 29). First Nations, fiscal equity \& resource sovereignties: The path to closing the development gap [Keynote address]. Canada 2020, Ottawa, Canada. http://www.afn.ca/uploads/files/final_3_nc_spkg_notes_canada 2020 public.pdf

Assembly of First Nations (AFN). (2015b, July 15). Assembly of First Nations National Chief urges premiers for action in partnership, presses federal government to come to the table [Press release]. https://www.afn.ca/7-15-15-assembly-of-first-nations-national-chief-urges-premiers$\underline{\text { for-ac/ }}$

Assembly of First Nations (AFN). (2019, September 9). Honoring promises: 2019 federal election priorities for First Nations [Press release]. https://www.afn.ca/the-afn-launches-honouringpromises-2019-election-priorities-for-first-nations-and-canada/

Baril, H., \& Journet, P. (2013, May 10). Appels d'offres en éolien: Les grands consommateurs ne veulent pas payer [Wind energy tenders: Large consumers do not want to pay]. La Presse. https://www.lapresse.ca/affaires/economie/energie-et-ressources/201305/10/01-4649638appels-doffres-en-eolien-les-grands-consommateurs-ne-veulent-pas-payer.php 
Campbell, D. (2011). More than wind: Evaluating renewable energy opportunities for First Nations in Nova Scotia and New Brunswick. https://ir.lib.uwo.ca/aprci/206/

Canning, P. C. (2018). I could turn you to stone: Indigenous blockades in an age of climate change. The International Indigenous Policy Journal, 9(3). https://doi.org/10.18584/iipj.2018.9.3.7

Carney, R. (1995). Aboriginal residential schools before Confederation: The early experience. Historical Studies, 61(1), 13-40.

Chambers, N. A. (2011). Reconciliation: A “dangerous opportunity” to unsettle ourselves. In G. Younging, J. Dewar, \& M. DeGagné (Eds.), Response, responsibility, and renewal: Canada's truth and reconciliation journey (pp. 259-275). Aboriginal Healing Foundation.

Cherp, A., \& Jewell, J. (2011). The three perspectives on energy security: Intellectual history, disciplinary roots and the potential for integration. Current Opinion in Environmental Sustainability, 3, 202-212. https://doi.org/10.1016/j.cosust.2011.07.001

Cleland, M., \& Gattinger, M. (2017). System under stress: Energy decision-making in Canada. https://www.uottawa.ca/positive-energy/sites/www.uottawa.ca.positive-energy/files/systemunder-stress.pdf

Cook, D., Fitzgerald, E., Sayers, J., \& Shaw, K. (2017). First Nations and renewable energy development in British Columbia. https://www.uvic.ca/research/assets/docs/rpkm/shaw-karenafirst_nations renewable_energy bc.pdf

Coulthard, G. S. (2010). Subjects of empire? Indigenous Peoples and the "politics of recognition" in Canada. University of Victoria.

Curry, B., \& Mittelstaedt, M. (2008, December 12). Ottawa's stand at climate talks hurting Native Rights, Chiefs say. The Globe and Mail. https://www.theglobeandmail.com/news/national/ ottawas-stand-at-climate-talks-hurting-native-rights-chiefs-say/article20391039/

Dalhousie University. (n.d.). Indigenous studies. https://dal.ca.libguides.com/ c.php?g $=576634 \& p=4205601$

Davine, T., Lawhon, M., \& Pierce, J. (2017). Place-making at a national scale: Framing tar sands extraction as "Canadian" in the Globe and Mail. The Canadian Geographer / Le géographe canadien, 61(3), 428-439. https://doi.org/10.1111/cag.12392

Dreveskracht, R. D. (2011). Native Nation economic development via the implementation of solar projects: How to make it work. Washington and Lee Law Review, 68(1), 28-112.

Dyck, N., \& Sadik, T. (2016, April 15). Indigenous political organization and activism in Canada. The Canadian Encyclopedia. 
Feltham-King, T., \& Macleod, C. (2016). How content analysis may complement and extend the insights of discourse analysis: An example of research on constructions of abortion in South African newspapers 1978-2005. International Journal of Qualitative Methods, 15(1). https://doi.org/10.1177/1609406915624575

Ferrara, N. (2015). Reconciling and rehumanizing Indigenous-settler relations: An applied anthropological perspective. Lexington Books.

Finegan, C. (2018). Reflection, acknowledgement, and justice: A framework for Indigenous-protected area reconciliation. The International Indigenous Policy Journal, $9(3) . \underline{\mathrm{https}}$ ///doi.org/ 10.18584/iipj.2018.9.3.3

Fullerton, R. S., \& Patterson, M. J. (2008). 'Killing' the true story of First Nations: The ethics of constructing a culture apart. Journal of Mass Media Ethics, 23, 201-218. https://doi.org/ $\underline{10.1080 / 08900520802222019}$

Garrick, R. (2017, November 22). 'We are an industry': Wesley-Esquimaux says at Indigenous Knowledge conference. Anishinabek News. http://anishinabeknews.ca/2017/11/22/we-arean-industry-wesley-esquimaux-says-at-indigenous-knowledge-conference/

Generation Energy Council. (2018). Canada's Energy Transition: Getting to our energy future, together. https://www.nrcan.gc.ca/sites/www.nrcan.gc.ca/files/energy/CoucilReport july4 EN_Web.pdf

Gibbins, R. (2017). Power to excel building a policy linchpin for the future of Canada's energy system. https://www.nrcan.gc.ca/sites/www.nrcan.gc.ca/files/energy/energyresources/Power to Exc el.pdf

Government of Canada. (2016). Pan-Canadian framework on clean growth and climate change. http://publications.gc.ca/collections/collection_2017/eccc/En4-294-2016-eng.pdf

Government of Canada. (2017). Pan-Canadian framework on clean growth and climate change, first annual synthesis report on the status of implementation. https://www.canada.ca/content/ dam/themes/environment/weather/climatechange/PCF-FirstSynthesis ENG.pdf

Government of Ontario. (2013). Achieving balance: Ontario's long-term energy plan. https://files.ontario.ca/books/ltep 2013 english_web.pdf

Government of Ontario. (2016). Ontario's five year climate change action plan 2016-2020. https://www.publications.gov.on.ca/ontarios-five-year-climate-change-action-plan-2016-2020

Government of Ontario. (2017). Ontario's long-term energy plan 2017: Delivering fairness and choice. https://files.ontario.ca/books/ltep2017 0.pdf

Green, J. (2003). Decolonization and recolonization in Canada. In W. Clement \& L. F. Vosko (Eds.), Changing Canada: Political economy as transformation (pp. 51-78). McGill-Queen's PressMQUP. 
Green, J. (2016). Red skin, white masks: Rejecting the colonial politics of recognition by Glen Coulthard (review). Great Plains Quarterly, 36(4), 327-328. https://doi.org/10.1353/ gpq.2016.0052

Green Energy and Green Economy Act, 2009, S.O. 2009, c. 12 - Bill 150. https://www.ontario.ca/ laws/statute/s09012

Green Party of Canada. (2019, October 5). Greens promise to end colonial oppression and phase out the Indian Act [Press release]. https://www.greenparty.ca/en/media-release/2019-1005/greens-promise-end-colonial-oppression-and-phase-out-indian-act

Hajer, M., \& Versteeg, W. (2005). A decade of discourse analysis of environmental politics: Achievements, challenges, perspectives. Journal of Environmental Policy \& Planning, 7(3), 175184. https://doi.org/10.1080/15239080500339646

Hallenbeck, J. (2015). Returning to the water to enact a treaty relationship: The Two Row Wampum Renewal Campaign. Settler Colonial Studies, 5(4). https://doi.org/10.1080/ $\underline{2201473 X .2014 .1000909}$

Harding, R. (2006). Historical representations of Aboriginal people in the Canadian news media. Discourse \& Society, 17(2), 205-235. https://doi.org/10.1177/0957926506058059

Hunter, D. (2019). John Cabot. The Canadian Encyclopedia. https://www.thecanadianencyclopedia.ca/en/article/john-cabot

Inuit Tapiriit Kanatami. (2015, April 22). The climate change bind for Inuit: The double burden of impacts \& campaigns. https://www.itk.ca/the-climate-change-bind-for-inuit-the-doubleburden-of-impacts-campaigns/

Jaffar, A. (2015). Establishing a clean economy or strengthening Indigenous sovereignty: Conflicting \& complementary narratives for energy transitions [Master's thesis, University of Guelph]. https://atrium.lib.uoguelph.ca/xmlui/bitstream/handle/10214/9230/Jaffar_Atiya_201509 MA.pdf? sequence $=1 \&$ isAllowed $=y$

Karanasios, K. (2018). Community choices: Pathways to integrate renewable energy into Indigenous remote community energy systems. University of Waterloo.

Karanasios, K., \& Parker, P. (2018). Technical solution or wicked problem? Diverse perspectives on Indigenous community renewable electricity in Northern Ontario. Journal of Enterprising Communities: People and Places in the Global Economy, 12(3), 322-345. https://doi.org/10.1108/JEC-11-2017-0085

Kekinusuqs. (2005). A nation's economic catalyst: How small First Nations can use CED to rebuild their economic independence. Making Waves, 16(4), 5-10. https://communityrenewal.ca/ sites/all/files/resource/MW160405.pdf 
King, H., \& Pasternak, S. (2018). Canada's emerging Indigenous Rights framework: A Critical analysis. Yellowhead Institute.

Krackle, J. (2015, December 3). Dokis Okikendawt Project brings green energy to Ontario consumers. Anishinabek News. http://anishinabeknews.ca/2015/12/03/dokis-okikendawt-project-bringsgreen-energy-to-ontario-consumers/

Krupa, J. (2012). Blazing a new path forward: A case study on the renewable energy initiatives of the Pic River First Nation. Environmental Development, 3, 109-122. https://doi.org/10.1016/ j.envdev.2012.05.003

Krupa, J., Galbraith, L., \& Burch, S. (2015). Participatory and multi-level governance: Applications to Aboriginal renewable energy projects. Local Environment, 20(1), 81-101. https://doi.org/ $\underline{10.1080 / 13549839.2013 .818956}$

Lowan-Trudeau, G. (2017). Indigenous environmental education: The case of renewable energy projects. Educational Studies, 53(6), 601-613. https://doi.org/10.1080/ $\underline{00131946.2017 .1369084}$

Manuel, A., \& Derrickson, G. C. R. (2017). The reconciliation manifesto: Recovering the land, rebuilding the economy. James Lorimer \& Company.

Marshall, T. (2019). Oka Crisis. The Canadian Encyclopedia. https://www.thecanadianencyclopedia.ca/en/article/oka-crisis

Mccreary, T. A., Milligan, R. A., \& Milligan, R. (2014). Pipelines, permits, and protests: Carrier Sekani encounters with the Enbridge Northern Gateway Project. Cultural Geographies, 21(1), 115 129. https://doi.org/10.1177/1474474013482807

McFarlane, P., \& Schabus, N. (Eds.). (2017). Whose land is it anyway? A manual for decolonization. Federation of Post-Secondary Educators of BC. https://fpse.ca/sites/default/files/ news files/Decolonization\%20Handbook.pdf

Meadowcroft, J. (2009). What about the politics? Sustainable development, transition management, and long term energy transitions. Policy Sciences, 42, 323-340. https://doi.org/10.1007/s11077$\underline{009-9097-z}$

Nagy, R. (2014). The Truth and Reconciliation Commission of Canada: Genesis and design. Canadian Journal of Law and Society / Revue canadienne droit et société, 29(2), 199-217. https://doi.org/10.1017/cls.2014.8

National Inquiry into Murdered and Missing Indigenous Women and Girls (MMIWG). (2019a). $A$ legal analysis of genocide: Supplementary report of the National Inquiry into Missing and Murdered Indigenous Women and Girls. https://www.mmiwg-ffada.ca/wpcontent/uploads/2019/06/Supplementary-Report_Genocide.pdf 
National Inquiry into Murdered and Missing Indigenous Women and Girls (MMIWG). (2019b). Reclaiming power and place: The final report of the National Inquiry into Missing and Murdered Indigenous Women and Girls. https://www.mmiwg-ffada.ca/final-report/

Natural Resources Canada. (2018). Generation Energy. https://www.nrcan.gc.ca/climatechange/canadas-green-future/generation-energy/20093

Natural Resources Canada. (n.d.). Generation Energyideas and submissions. https://www.nrcan.gc.ca/climate-change/canadas-green-future/generationenergy/generation-energy-ideas-and-submissions/20243

Ozog, S. (2012). Towards First Nations energy self-sufficiency: Analyzing the renewable energy partnership between T'Sou-Ke Nation and Skidegate Band. University of Victoria.

Quinn, J. R. (2011). Introductory essay: Canada's own brand of truth and reconciliation? The International Indigenous Policy Journal, 2(3). https://doi.org/10.18584/ iipj.2011.2.3.1

Rodman, L. S. (2013). Spinning wind into power: Industry and energy in Gitxaała Nation, British Columbia [Master's thesis, University of British Columbia]. http://hdl.handle.net/2429/44518

Royal Commission on Aboriginal Peoples (RCAP). (1996). Report of the Royal Commission on Aboriginal Peoples (Vol. 1: Looking forward, looking back). https://data2.archives.ca/e/e448/ e011188230-01.pdf

Rymhs, D. (2006). Appropriating guilt: Reconciliation in an Aboriginal Canadian context. ESC: English Studies in Canada, 32(1), 105-123. https://doi.org/10.1353/esc.2007.0068

Sovacool, B. K. (2014). What are we doing here? Analyzing fifteen years of energy scholarship and proposing a social science research agenda. Energy Research \& Social Science, 1, 1-29. https://doi.org/10.1016/j.erss.2014.02.003

Stanton, K. (2011). Canada's Truth and Reconciliation Commission: Settling the past? The International Indigenous Policy Journal, 2(3). https://doi.org/10.18584/iipj.2011.2.3.2

Stanton, K. (2017). Reconciling reconciliation: Differing conceptions of the Supreme Court of Canada and the Canadian Truth and Reconciliation Commission. Journal of Law and Social Policy, 26, $21-42$.

Statistics Canada. (2017, October 25). Aboriginal peoples in Canada: Key results from the 2016 Census. The Daily. https://www150.statcan.gc.ca/n1/daily-quotidien/171025/dq171025a-eng.htm

Stefanelli, R. D., Walker, C., Kornelsen, D., Lewis, D., Martin, D. H., Masuda, J., Richmond, C. A. M., Root, E., Tait Neufeld, H., \& Castleden, H. (2019). Renewable energy and energy autonomy: 
How Indigenous Peoples in Canada are shaping an energy future. Environmental Reviews, $27(1), 95-105$. https://doi.org/10.1139/er-2018-0024

Tobias, J. K., \& Richmond, C. A. M. (2014). “That land means everything to us as Anishinaabe ....”: Environmental dispossession and resilience on the North Shore of Lake Superior. Health \& Place, 29, 26-33. https://doi.org/10.1016/j.healthplace.2014.05.008

Tonkiss, F. (2004). Analysing text and speech: Content and discourse analysis. Researching Society and Culture, 2, 367-382.

Truth and Reconciliation Commission of Canada. (2015). Honouring the truth, reconciling for the future: Summary of the final report of the Truth and Reconciliation Commission of Canada. http://www.trc.ca/assets/pdf/Executive_Summary_English_Web.pdf

University of British Columbia. (n.d.). First Nations and Indigenous studies. https://guides.library.ubc.ca/c.php?g=307187\&p=2050818

University of Ottawa. (2015). Canadians' views on Canada's energy future. https://www.uottawa.ca/ positive-energy/sites/www.uottawa.ca.positive-energy/files/positive energy big ideas survey research 2015-11-06.pdf

Veracini, L. (2011). Introducing settler colonial studies. Settler Colonial Studies, 1(1), 1-12. https://doi.org/10.1080/2201473X.2011.10648799

White, J. P., Murphy, L., \& Spence, N. (2012). Water and Indigenous Peoples: Canada's paradox. The International Indigenous Policy Journal, 3(3). https://doi.org/10.18584/iipj.2012.3.3.3

Wilmer, F. (1993). The Indigenous Voice in world politics: Since time immemorial. Sage Publications. 